\title{
Effect of Instructional Package on Pregnant Women's Knowledge and Attitude regarding Healthy Nutrition
}

\section{Azza Abd Elhamied Abdel Fatah Ahmed ${ }^{1}$, Mohammed Abdel Salam Mohammed ${ }^{2}$, Soad Abdel Salam Ramadan ${ }^{3}$ and Amira Mohammed Salama ${ }^{4}$}

(1) (Master Degree in Maternal \& Newborn Health Nursing2016), Nursing specialist in technical institute of Nursing, Benha university,(2)Professor of Obstetrics and Gynecology Faculty of Medicine University Benha, (3) Prof. Dr of Obstetrics and woman health nursing Faculty of nursing Benha university and (4) Lecturer of Obstetrics and woman health Nursing ,Benha University.

\begin{abstract}
Background: Healthy nutrition during pregnancy helps to maintain normal growth and development of the fetus, improve delivery outcomes and prevent childhood diseases later in life. Aim of this study: Was to evaluate the effect of instructional package on pregnant women's knowledge and attitude regarding healthy nutrition. Design: A quasi experimental pre/ post- test one-group. Setting: This study was conducted in obstetrics and gynecological outpatient clinic at Benha university hospital. Sample: A Purposive sampling of 100pregnant woman Tools:A structured interviewing questionnaire, knowledge of studied pregnant women regarding healthy nutrition and attitude of studied pregnant women regarding healthy nutrition Results: Total knowledge score regarding healthy nutrition were greatly improved after instructional package implementation than before implementation among studied pregnant women. total attitude regarding healthy nutrition were greatly improved after instructional package implementation than before implementation among studied pregnant women. Conclusion: There was statistical significant correlation between total knowledge and total attitude among studied pregnant women pre instructional package implementation $(\mathrm{P}<0.05)$. While there was a highly statistically significant correlation at post instructional package implementation $(\mathrm{P} \leq 0,001)$. Therefore, the study hypothesis was supported. Recommendation: Posters and educational materials about healthy nutrition during pregnancy should be located in well-visible areas in outpatients' and private clinics.
\end{abstract}

Key words: Instructional package, Pregnant Women, Knowledge, Attitude, Healthy nutrition.

\section{Introduction}

Pregnancy is a time of increased energy and nutrient needs for a woman in order to meet the needs of the growing fetus and of maternal tissues associated with pregnancy, proper dietary balance is necessary to ensure sufficient energy intake for adequate growth of fetus without drawing on mother's own tissues to maintain her pregnancy (Wemakor, 2019).

Under nutrition has the most damaging effect on the fetus during pregnancy and in the first two years of life, and the effects of this early damage on health,brain development, intelligence, educability, and productivity are largely irreversible ( Rupali,2020).
Nutrition plays an important and definite role in the course of pregnancy for the maintenance of sound maternal health. To meet nutritional needs, pregnant women are encouraged to consume a diet rich in vegetables, fruits, whole grains, protein, fats and carbohydrates, and to take a daily vitamin and mineral supplement to guarantee adequate intake of iron and folic acid ( Ülger et al.,2018).

Healthy nutrition during pregnancy helps to maintain normal growth and development of the fetus. It also helps to improve delivery outcomes and prevent childhood diseases later in life, such as heart diseases and obesity (Tahir et al., 2019). 
During pregnancy, unhealthy nutrition of the mother or an inability to meet the nutritional requirements leads to some health problems for the mother and the infant such as anaemia, osteomalacia and pregnancy toxaemia can be seen in pregnancy. Other risk factors may be increased such as stillbirth, premature birth, congenital anomalies and mental retardation. Risks increase in infants due to insufficient and unbalanced nutrition (Koletzko et al., 2019).

There are many significant effects of nutrition during pregnancy in the short and long -term health of the mother, fetus and infants; it is known that pregnant women are most affected by the insufficient and unbalanced nutritional problems in the developing countries (Paknahad et al., 2019). The main causes for inadequate and unbalanced nutrition of pregnant women are failure to intake nutritional supplements required for increasing needs of pregnancy and lactation, failure to purchase nutrients that are suitable in nutritional content due to low socioeconomic status, wrong nutrient selection due to tradition and customs, mistakes during storage, preparation and cooking of foods (Desta et al., 2019)

Pregnancy is an important time to increase women's awareness about healthy eating. Pregnant women recognize diet as important to fetal health and are more likely to be mindful of nutrition, seek health advice, and modify their diets. Nutrition knowledge has been positively associated with maternal dietary behavior and use of supplements. (Tsegaye et al., 2020).

Nutrition education is the foundation for any program intended for nutritional improvement. The knowledge about proper nutrition and a balanced diet during pregnancy are considered important for the well-being of both mother and fetus. Nutrition instructional package is a widely used strategy to improve the nutritional status of woman during pregnancy .It target at enhancing subjects dietary intake by promoting a change of behavior such as food choice and cooking ability, goal setting, motivation and support the efforts for a change (Sunuwar et al., 2019).

Nurses are health care professionals essential to provide nutrition advice to pregnant women due to their usual contact with the women through antenatal care. Moreover, health promotion and education are considered the most important activities that nurses perform with pregnant women as advocates for health and wellbeing rather than managers of diseases (Yu Qi et al., 2020).

\section{Significance of the Study:}

Today, nearly one in three persons globally suffers from at least one form of malnutrition .Women of reproductive age are especially vulnerable to chronic energy deficiency and other malnutrition. Globally, approximately $13 \%$ of women were estimated to be undernourished . Maternal and child malnutrition is the underlying cause of 3.5 million deaths(Yan et al.,2020)The main nutritional issues impacting pregnant women were protein and energy under nutrition and deficiencies of micronutrients, such as iron, folate, calcium, vitamin D and vitamin A .Globally, $38 \%$ of all pregnant women suffered from anemia and contributing for $20 \%$ of maternal mortality ( Herring et al.,2018) (Sarah et al.,2020) (Berhe et al.,2019).

Maternal mortality and morbidity rates due to pregnancy and childbirth in developing countries are quite high. Of these $99 \%$ of deaths occurred in developing countries. High maternal mortality rate caused by complications in pregnancy and childbirth.(Temesgen \& Ayenew., 2020).

Anemia is a significant public health problem all around the globe. The prevalence of anemia in pregnancy varies in different series from various parts of the world. According to WHO estimates, 35-75\% (average 56\%) pregnant females in developing countries suffer from anemia .The worldwide prevalence of anemia during 
pregnancy was estimated to be $38 \%$ in the Nutrition Impact Model (Sharma et al.,2020).

\section{Aim of the study:}

The study aimed to evaluate the effect of instructional package on pregnant women's knowledge and attitude regarding healthy nutrition .

\section{Research Hypothesis}

Pregnant women will have better knowledge and attitude regarding healthy nutrition after implementation of instructional package than before .

\section{Subjects and Method \\ Study Design:}

A quasi-experimental research design was used pre/post-test, one group was studied.

\section{Study Setting :}

This research was conducted at obstetrics \& gynaecological outpatient clinic in Benha university hospital.

\section{Sampling}

$$
\text { Sample type }
$$

\section{Sample size:}

100 pregnant women was admitted to pre mention setting at Benha University Hospital . The studied sample was selected according to the following:Inclusion criteria: The woman must be confirmed pregnant with single baby and agree to participate in the study, women attending antenatal clinic at first and second trimester of pregnancy, women can read and write and women with no pregnancy complications and free from any medical disorders.

\section{Tools of data collection:}

Three main tools were used for data collection

First tool: AStructured interviewing questionnaire.It was designed by the researcher after reviewing related literature, it was written in an Arabic language. It was consisted of two parts:

Part I: Socio-demographic data of women, it consisted of (age, level of education, occupation, marital status ,residence and type of family). Part II : Obstetrical history of pregnant women, it consisted of (age at marriage ,gestational age, number of pregnancy, trimester of pregnancy, planning for pregnancy, number of abortion and number of children).

Secondtool:MaternalKnowledgeQuestionnair e about healthy nutrition :It was adapted from (Karaponi et al., 2016) and was translated into Arabic language by the researcher. This part used before and after implementation of instructional package (pre/post test format ). It consisted of questions to measure maternal knowledge regarding healthy nutrition during pregnancy. and consisted of (6) sections. First section included general knowledge regarding healthy nutrition during pregnancy (7 items), Second section included knowledge of pregnant woman about diet system during pregnancy (17 items), Third section included knowledge pregnant woman about the components of the food pyramid during pregnancy (6 items), Fourth section included knowledge of pregnant woman about nutritional supplements during pregnancy (18 items), Fifth section included knowledge of pregnant woman about integrated meal during pregnancy ( 8 items), and Sixth section included knowledge of pregnant woman about the health guidelines for healthy eating during pregnancy (27 items).

\section{Scoring system :}

Woman's knowledge was calculated for each item as the following: Each item was assigned a score ( 2) was given when the answer was completely correct, a score (1) was given when the answer was incompletely correct and a score (0) was given when the answer was unknown or incorrect. The knowledge score was calculate by adding the scores for the correct answers. The higher scores reflect higher levels of knowledge about healthy nutrition during pregnancy .

As well as, women' total knowledge score was classified as the following:

Poor knowledge ----------- $<60 \%$ of total knowledge score.

Average knowledge ------- $60-75 \%$ of total knowledge score.

Good knowledge -------- > 75\% of total knowledge score. 
Third tool: Maternal Health Attitude Questionnaire (MHAQ):

The MHAQ was adapted from ( Dana et al.,2018) and was translated into Arabic language by the researcher .This part used before and after implementation of instructional package (pre/post test format ) .These questions are about attitude of healthy nutrition during pregnancy.

\section{Scoring system :}

Scoring system of attitude :Agree attitude was score "2", unsure(neutral) attitude was score "1" and the disagree attitude was score " 0 ". The attitude score was calculate by adding the scores for the agree attitude . the higher scores reflect higher levels of attitude about healthy nutrition during pregnancy.

The total score of attitude was calculated as :

- Positive attitude: $\geq 75 \%$ of total attitude score

-Uncertain attitude: $60 \%-75 \%$ of total attitude score.

-Negative attitude: $<60 \%$ of total attitude score.

\section{Tools Validity and Reliability:}

The tools of data collection were submitted to a panel of three nursing experts in the field of obstetrics and gynaecology to test the content validity, modification were carried out according to the panel' judgments on clarity of sentences and the appropriateness of content. The reliability was done by Cronbach's Alpha coefficient test which revealed that each of the two tools consisted of relatively homogenous items as indicated by the moderate to high reliability of each tool .

\section{Ethical considerations:}

An official permission from the selected study settings was obtained for the fulfillment of the study.

- $\quad$ The aim of the study was explained to all pregnant women before applying the tools to gain their confidence and trust.

Oral consent was obtained from pregnant women to participate in the study and confidentiality was assured.
- The data was collected and treated confidentially.

- $\quad$ The study would not cause any physical ,social or psychological risk of the women.

- Freedom to withdrawal at any time of data collection and with no obligation.

\section{A Pilot Study}

The pilot study was carried out on $10 \%$ of total sample(10 women) to test the simplicity, clarity and applicability of the study tools as well as estimation of the time needed to fill the questionnaire. According to the results of the pilot study, required modifications were done in the form of adding, omission or paraphrasing of some questions. Women involved in the pilot excluded from the study to avoid contamination of the sample.

\section{Field Work}

The study was carried out from the beginning of April, 2019 and completed at the end of April , 2020 covering one year. The researcher visited the previously mentioned setting two days/week, (Sunday, Thursday), from 9.00 Am to $12.00 \mathrm{Pm}$ according to the schedule of obstetrics and gynecological outpatient clinic.the following phases were adopted:

A. Preparatory phase: The researcher carried out through review of local and international related literature about the various aspects of the research problem. The researcher interviewed the pregnant women after reviewing medical record, ensure of health status, explained the aim of the study, and asked for participation. Upon consent to participate, each pregnant woman was interviewed to assess general characteristics, knowledge and attitude regarding healthy nutrition. The data was obtained during this phase was constituted the baseline for further comparisons to evaluate the effect of instructional package on pregnant women's knowledge and attitude regarding healthy nutrition .

B. Interviewing and assessment phase: At the beginning of interview the researcher greeted the woman, introduced herself to each 
woman included in the research, explained the purpose of the research and provided the woman with all information about the research and take oral consent to participate in the research. Data were collected by the researcher through administration of the tools (structured interviewing questionnaire, maternal knowledge questionnaire and maternal health attitude questionnaire ) to each woman. Average time for the completion of each woman interview was around (20-25 minutes). The questionnaire was filled by the researcher during waiting time of the women during their antenatal visits. A number of interviewed women / week ranged from (810) women..

C. Planning phase: Based on results obtained from pregnant woman during assessment phase, the instructional package was developed by the researcher in a form of printed Arabic booklet to satisfy the studied pregnant women's deficit knowledge and attitude regarding healthy nutrition during pregnancy. Sessions number and its contents, different methods of teaching, and instructional media were determined accordingly to pregnant woman . Objectives of instructional package were constructed and included the following:

\section{General Objective}

By the end of the instructional package' sessions, each woman in the study will be able to acquire essential knowledge and healthy attitude regarding healthy nutrition and will be satisfied with the instructional package regarding healthy nutrition.

\section{Specific Objectives}

By the end of the instructional package' sessions, each woman in the study will be able to:

- Define healthy nutrition during pregnancy .

-Discuss important diet system on maternal and fetus during pregnancy .

- Discuss food pyramids during pregnancy and components of food pyramids.

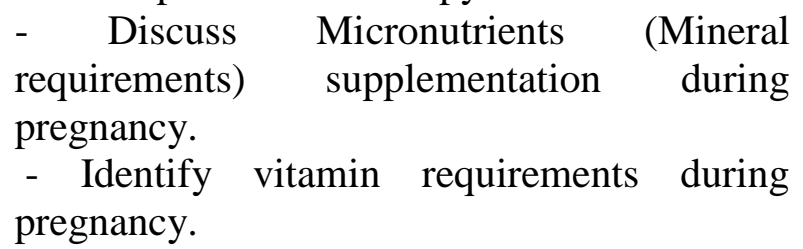

- Identify problems associated with nutrition during pregnancy .

- Enumerate foods that must be avoided during pregnancy(Foods to be limited).

-Adopt healthy attitude during pregnancy.

D. Implementation of the instructional package phase: Pregnant women received routine care by hospital staff, in addition to participated in the instructional package through three scheduled sessions. Each session took about 45-60 minutes. At the beginning of the first session women were oriented with the instructional package' contents. Each woman was informed about the time of the next sessions at the end of the session. The subsequent session started by a feedback about the previous session and the objectives of the new session, simple Arabic language was used to suit women' level of understanding. At the end of each session, women' questions were discussed to correct any misunderstanding.

The First session of the instructional package implementation began during the women' first visit that follow the interviewing phase and included, define healthy nutrition during pregnancy and diet system during pregnancy and it's effect on maternal and fetal condition and Discuss food pyramids during pregnancy .

The Second session of the instructional package implementation began during the women' second visit that included maternal dietary consumption during pregnancy and Micronutrients (Mineral requirements) supplementation during pregnancy and Vitamin requirements during pregnancy.

The Third session of the instructional package implementation began during the women' third visit that included problems associated with nutrition during pregnancy, foods that must be avoided during pregnancy(Foods to be limited) and healthy attitude during pregnancy .These sessions were repeated to each subgroup of (8-10) women. Different methods of teaching were used such as discussion, demonstration, redemonstration and brainstorming. Instructional media included videos contain all content of the instructional package and 
educational booklet about healthy nutrition which constructed by the researcher in a simple Arabic language after reviewing the related literatures were distributed to all recruited women in the study to achieve its objectives.

E- Evaluation phase: During this phase, the effect of the instructional package was evaluated (posttest) by using the same format of tools which were used before the implementation of the instructional package (pretest). Immediate evaluation was conducted after the implementation of the instructional package to evaluate woman' knowledge gain and attitude about healthy nutrition .

\section{Statistical analysis:}

Data was verified prior to computerized entry. The Statistical Package for Social Sciences (SPSS version 22.0) was used for that purpose, followed by data tabulation and analysis. Descriptive statistics were applied (e.g., mean, standard deviation, frequency and percentages). Test of significance ( $t$ test, chisquare). as well as person correlation coefficient was used to investigate relation between study variables .A significant level value was considered when $\mathrm{p} \leq 0.05$. In addition, A highly significant level value was considered when $\mathrm{p}<0.001$.

\section{Results}

Table (1): Reveals that, nearly half of studied pregnant women 's age ranged from (20 to less than 25 years) with mean standard \pm SD $23.67 \pm 6.49$, nearly one third of them could read and write and also had secondary education ,more than three quarters of them were house wife and nearly two thirds of them had nuclear type of family .In relation to the residence majority of them were living in rural .

Table(2): Illustrates that , majority of studied pregnant women $(89 \%)$ had 20 to less than 25 years age at marriage, two thirds of them $(66 \%)$ had less than 20 weeks of gestational weeks ,nearly half of them $(58 \%)$ were in first trimester of pregnancy period,more than three quarters of them $(76 \%)$ had no abortion, more than half of them $(60 \%)$ had from two children.

Figure (1): Displays that ,nearly two fifth of studied pregnant women(41\%) had their information from friends and one third of them $(32 \%)$ from medical sources.

Figure (2): Represents that, Total knowledge score regarding healthy nutrition were greatly improved after instructional package implementation than before implementation among studied pregnant women.

Figure(3) : Represents that, total attitude regarding healthy nutrition were greatly improved after instructional package implementation than before implementation among studied pregnant women.

Table (3): Shows that, there was statistical significant correlation between total knowledge and total attitude among studied pregnant women pre instructional package implementation $(\mathrm{P}<0.05)$.While there was a highly statistically significant correlation between total knowledge and total attitude among studied pregnant women at post instructional package implementation (P $\leq \mathrm{o}, \mathrm{oo} 1)$. 
Table (1): Distribution of studied pregnant women regarding sociocharacteristics $(\mathbf{n}=\mathbf{1 0 0})$

\begin{tabular}{|c|c|c|}
\hline Personnel characteristics & N0. & $\%$ \\
\hline \multicolumn{3}{|l|}{ Age in years } \\
\hline$<20$ & $\overline{3}$ & 3.0 \\
\hline $20-<25$ & 45 & 45.0 \\
\hline $25-<30$ & 44 & 44.0 \\
\hline$\geq 30$ & 8 & 8.0 \\
\hline Mean \pm SD & \multicolumn{2}{|c|}{$23.67 \pm 6.49$} \\
\hline \multicolumn{3}{|l|}{ Educational level } \\
\hline Read and write & 36 & 36.0 \\
\hline Secondary & 36 & 36.0 \\
\hline University & 27 & 27.0 \\
\hline Postgraduate & 1 & 1.0 \\
\hline \multicolumn{3}{|l|}{ Occupation } \\
\hline House wife & 80 & 80.0 \\
\hline Employee & 20 & 20.0 \\
\hline \multicolumn{3}{|l|}{ Marital status } \\
\hline Married & 100 & 100.0 \\
\hline Divorced & 0 & 0.0 \\
\hline Widow & 0 & 0.0 \\
\hline \multicolumn{3}{|l|}{ Type of family } \\
\hline Nuclear & 65 & 65.0 \\
\hline Extended & 35 & 35.0 \\
\hline \multicolumn{3}{|l|}{ Residence } \\
\hline Urban & 7 & 7.0 \\
\hline Rural & 93 & 93.0 \\
\hline
\end{tabular}

Table (2): Distribution of studied pregnant women regarding obstetric history $(\mathrm{n}=100)$

\begin{tabular}{|c|c|c|}
\hline Obstetric history & No. & $\%$ \\
\hline \multicolumn{3}{|l|}{ Age at marriage } \\
\hline$<20$ & 2 & 2.0 \\
\hline $20-<25$ & 89 & 89.0 \\
\hline $25-<30$ & 8 & 8.0 \\
\hline$\geq 30$ & 1 & 1.0 \\
\hline \multicolumn{3}{|l|}{$\overline{\text { Gestational age( weeks) }}$} \\
\hline Less than 20 weeks & 66 & 66.0 \\
\hline$\geq 20$ weeks & 34 & 34.0 \\
\hline \multicolumn{3}{|l|}{$\overline{\text { Number of pregnancy }}$} \\
\hline 1 (primi gravida) & 21 & 21.0 \\
\hline 2 (gravida 2) & 29 & 29.0 \\
\hline 3 (gravida 3) & 30 & 30.0 \\
\hline$>3$ times (>gravida 3 ) & 20 & 20.0 \\
\hline \multicolumn{3}{|c|}{ Pregnancy period ( trimester pregnancy) } \\
\hline First trimester & 58 & 58.0 \\
\hline Second trimester & 42 & 42.0 \\
\hline \multicolumn{3}{|l|}{ Planning for pregnancy } \\
\hline Yes & 50 & 50.0 \\
\hline No & 50 & 50.0 \\
\hline \multicolumn{3}{|l|}{ Number of abortion } \\
\hline No occurred & 76 & 76.0 \\
\hline $1-2$ times & 16 & 16.0 \\
\hline$\geq 3$ times & 8 & 8.0 \\
\hline \multicolumn{3}{|l|}{ Number of children } \\
\hline One & 26 & 26.0 \\
\hline Two & 60 & 60.0 \\
\hline$\geq 3$ & 14 & 14.0 \\
\hline
\end{tabular}




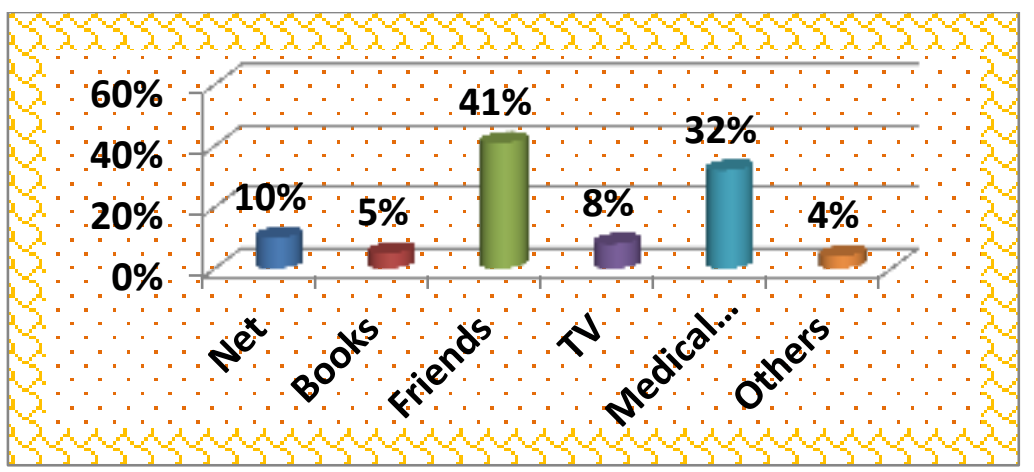

Figure (1): Distribution of women's' sources of information regarding healthy nutrition during pregnancy

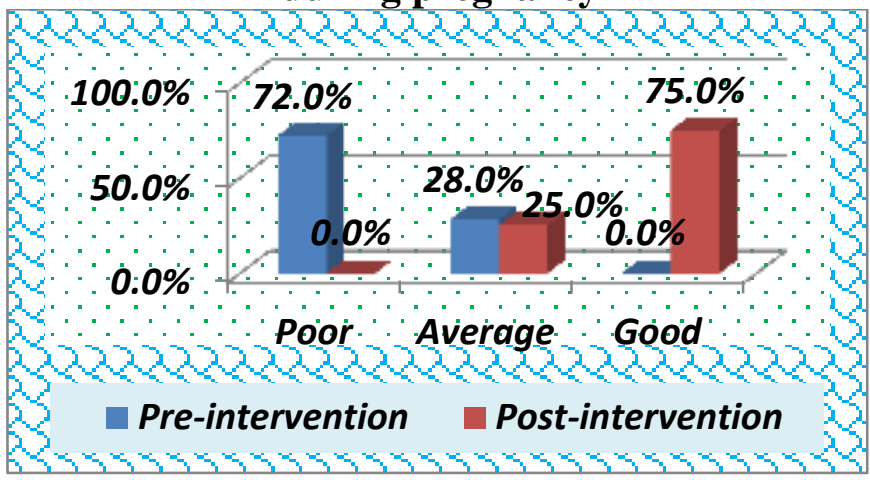

Figure(2):Distribution of total knowledge score of the studied pregnant women regarding healthy nutrition pre and post instructional package implementation

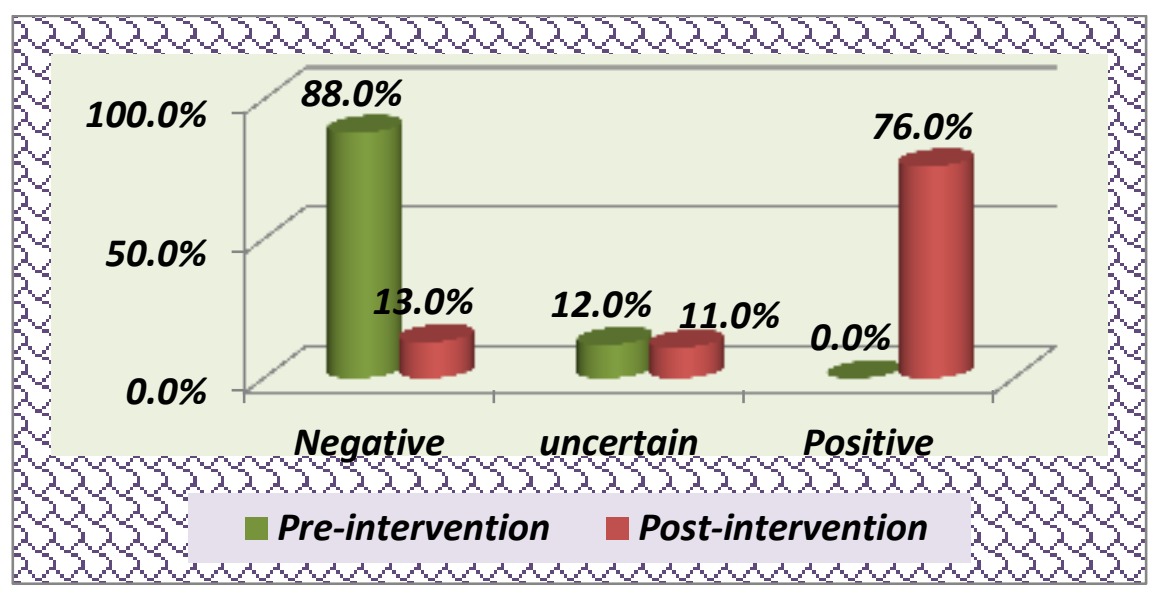

Figure (3):Distribution of total attitude score of the studied pregnant women regarding healthy nutrition pre and post instructional package implementation

Table (3):Correlation between studied pregnant women total knowledge and total attitude score pre and post instructional package implementation $(\mathbf{n}=100)$

\begin{tabular}{|c|c|c|c|c|}
\hline \multirow{3}{*}{$\begin{array}{l}\text { Total knowledge } \\
\end{array}$} & \multicolumn{4}{|c|}{ Total attitude } \\
\hline & \multicolumn{2}{|c|}{ Pre- implementation } & \multicolumn{2}{|c|}{ Post-implementation } \\
\hline & $\mathbf{r}$ & P value & $\mathbf{r}$ & P value \\
\hline Pre-intervention & 0.243 & $<0.05 *$ & - & - \\
\hline Post-intervention & - & - & 0.476 & $<0.001 * *$ \\
\hline
\end{tabular}




\section{Discussion:}

Socio-demographic characteristics can play a major role in determining healthy nutrition among studied pregnant woman. Regarding age of studied pregnant woman , the findings of the present study revealed that majority of studied pregnant women's age ranged between 20-30 years (at reproductive age) with mean age $23.67 \pm$ 6.49), This may be due to that studied pregnant women were selected in the range of (20-30yrs.) at reproductive age or this might be related to the effect of parity on increasing maternal age. This findings agrees with Benjamin et al.,( 2016) who studies sociodemographic and obstetric characteristics of anaemic pregnant women attending antenatal clinic in Bolgatanga Regional Hospital and found that $76.5 \%$ of pregnant women aged from $20<30$ years . However, those finding of the present study disagree with , Hanan ,(2019) who conducted study on effect of nutrition education package on pregnant women knowledge and healthy dietary practice reported that $57.3 \%$ of studied pregnant women aged from 20-30 yrs.

Regarding education level, the findings of the present study revealed that nearly one thirds $(39 \%)$ of studied pregnant women is read and write and had also secondary education and one quarter of them had university education this finding is in agreement with Heba.,(2017) who conducted study on diet behavior modification of pregnant woman with iron deficiency anemia using construct of the trans-theoretical model: a theory-based study and found that educational qualification- primary or preparatory education was $32.9 \%$ and secondary education was $37.0 \%$ and university education was $30.1 \%$. Moreover, this finding of the present study disagree with Nana\& Zema. ,(2018) who conducted study on dietary practices and associated factors during pregnancy in northwestern Ethiopia and found that $10.1 \%$ of pregnant woman read and write and $31.0 \%$ of them had higher institution .
Regarding occupation, the findings of the present study revealed that majority of studied pregnant women were housewife and one quarter of them were employee .This may be due to natural of area residence where majority of them live in rural area, This finding is in accordance with Sezer et al., (2017) who studies on knowledge, attitudes and behaviors of pregnant women about food safety: a cross sectional survey and found that $83.1 \%$ of them were housewife .However ,this finding of the present study disagree with ,Demilew et al, (2020) who conducted study on dietary practices and associated factors among pregnant women in west gojjam zone, northwest Ethiopia and reported that 51.2\% of woman had housewife and $48.8 \%$ of them were employee.

Regarding marital status, the findings of the present study revealed that all $(100 \%)$ of studied pregnant women were married this may be due to select sample of research ,this finding of the present study agree with Zelalem et al.,(2017) who conducted study on effect of nutrition education on pregnancy specific nutrition knowledge and healthy dietary practice among pregnant women in Addis Ababa found that the majority of the study participants( $91.6 \%$ ) were currently married.On the other hand, this finding of the present study disagree with Kara et al .,(2016) who conducted study on African American and white women's perceptions of weight gain, physical activity, and nutrition during pregnancy and reported that $30 \%$ of them were married and $70 \%$ of them were single.

As regards type of family, the findings of the present study revealed that nearly two thirds of studied pregnant women belonged to a nuclear family and more than one thirds of them belonged to extended family this may be due to natural of their social where desire of woman to live alone with husband. this finding of the present study agree with Nahrisah et al., (2020) who conducted study on effect of integrated pictorial handbook education and counseling on improving anemia status ,knowledge, food 
intake, and iron tablet compliance among anemic pregnant women in Indonesia: a quasi-experimental study and found that $87.1 \%$ of studied woman belonged to a nuclear Family and $12.9 \%$ of them belonged to other Extended family . However, this finding of the present study disagree with Noha \& Asmaa, (2019) who conducted study on dietary knowledge, practices and adequacy among Bedouin pregnant women and found that slightly more than one-fourths $(28.4 \%)$ of them lived in extended families and $71.6 \%$ of them lived in nuclear family .

Regarding residence, the findings of the present study revealed that majority of studied pregnant women were rural and 7\% of urban This result may be attributed to the outpatient clinic in benha University as it is accessible and visible for a large portion of the population, especially who live in rural areas with low and middle socio economic status; also this service offer with minimal charge. This finding agree with Daba G et al.,(2015) who conducted study on assessment of knowledge of pregnant mothers on maternal nutrition and associated factors in Guto Gida Woreda, East Wollega Zone, Ethiopia and found that about $95.7 \%$ of them were living in rural and $4.3 \%$ of them were living in urban. However, this finding of the present study disagree with Jessica et al.,( 2020) who conducted study on prevalence of anaemia and low intake of dietary nutrients in pregnant women living in rural and urban areas in the Ashanti region of Ghana and found that more than half $(59.1 \%)$ of them were resident in urban areas whiles the remaining $40.9 \%$ were resident in rural areas. Regarding marriage age, the findings of the present study revealed that majority of studied pregnant women ranged from 20-25 yrs. This may be due to natural of their social in rural. This findings agree with Fallah et al.,(2016) who conducted study effects of nutrition education on levels of nutritional awareness of pregnant women in Western Iran found that $88 \%$ had a marriage age of over 18 years. However ,this finding of the present study disagree with Oumer,(2019) who conducted study on knowledge, attitude and practice of pregnant mothers towards preventions of iron deficiency anemia in Ethiopia: institutional based cross sectional study and found that $25.8 \%$ of them with age at first marriage in years 21-25.

Regarding number of pregnancy, the findings of the present study revealed that one quarter of studied pregnant women at Primigravida( $1 \mathrm{st}$ ) and more than one quarter of them were Gravid 2(G2nd) and nearly one third of them were Gravid 3(G3th )and less than one quarter of them were Grande multigravida $(\geq 4$ th $)$ this may be thinking about having children idea.This findings agree with Nahrisah et al, (2020) who found that $17.9 \%$ of them were primigravida(1st) and $48.6 \%$ of them were multigravida(2nd3 th) and $33.5 \%$ of them were grande multigravida $(\geq 4$ th $)$. On the other hand ,this finding of the present study disagree with Zelalem et al,(2017) who found that $51.2 \%$ of them were primigravida and $48.8 \%$ of them were multigravida.

Regarding pregnancy period (trimester of pregnancy), the findings of the present study revealed that nearly half of studied pregnant women at first trimester of pregnancy and nearly three quarters at second trimester this due to select this sample. This findings agree with Jessica et al., (2020) who found that with regards to pregnancy period, majority of the mothers were in their second trimester.On the other hand, this finding of the present study disagree with Estela et al.,(2020) who conducted study on factors associated with insufficient weight gain among Mexican pregnant women with HIV infection receiving antiretroviral therapy and found that $57.1 \%$ of them most were already in their second pregnancy.

Regarding planning for pregnancy, the findings of the present study revealed that half of studied pregnant women were planned for occurring pregnancy and other half of them unplanned for occurring pregnancy this may be desire of woman in that this finding of the present study agree with Karaponi et al.,(2016) who conducted study on knowledge and beliefs about nutrition and physical activity during pregnancy in women from 
South Auckland region, New Zealand Australian and New Zealand and found that $49.7 \%$ of them planned pregnancy and $49.8 \%$ of them non planned pregnancy.

However, this finding of the present study disagree with Bookari et al.,(2016) who found that $81.2 \%$ of them were planned their pregnancy and $18.8 \%$ of them were non planned their pregnancy .

Regarding number of abortion ,the findings of the present study revealed that more than three quarter of studied pregnant women no occurred abortion and minority of them occur from 1-2 times abortion and 8.0\% occur more than three times this may be un known cause, this finding of the present study agree with Ekbal et al.,(2019) who conducted study knowledge and attitude of women and nurses regarding pre-conception care: a comparative study" and found that $71.5 \%$ of them no occur abortion and also found that disagree $28.5 \%$ of them occur one times. Also, this finding of the present study agree withEstela et al.,(2020) who found that no occur abortion and $18.8 \%$ occur abortion from $1-2$

Regarding number of children, the findings of the present study revealed that one quarter of studied pregnant women had one child and more than half of them had two child and minority of them had more than three children this may desire in having children idea .Moreover ,this finding of the present study agree with Ade et al.,(2015) who conducted study physical activity and energy expenditure: findings from the Ibadan pregnant women's survey and found that $26.9 \%$ of them had one child. On the other hand,this finding of the present study disagree with T. Morris et al.,(2020)who conducted study improving pregnant women's diet and physical activity behaviours: the emergent role of health identity BMC pregnancy childbirth and found that approximately half of the them $47 \%$ of them had only one child and two child and also $6 \%$ of the them had three child .

As regards the source of information about healthy nutrition, the results of current study showed that nearly one third of studied pregnant women had source of information from friends and families and nearly one third of them had source of information from medical resources . This may be due to that family members could potentially provide legitimate and reputable nutrition knowledge, especially if they are a family member that has had children and has passed down advice that was either given to them by a healthcare provider or from another knowledgeable family member. This finding of the present study disagree with Dana .,et al,(2018) who study on knowledge, attitude and practices toward nutrition and diet during pregnancy among recently delivered women of Syrian Refugees and found that source of nutritional information from $\mathrm{ANC/}$ doctors clinic was $50 \%$ and from family/ friends was $25 \%$ and from TV/ Radio was $10 \%$ and from school was $8 \%$ and from others was $1 \%$ and $6 \%$ of them didn't receive any information .

Regarding knowledge of studied pregnant women for nutritional supplement(Micronutrient) during pregnancy pre and post instructional package implementation and found that there was a highly statistically significant difference regarding knowledge about nutritional supplement among studied pregnant women at pre and post phases of instructional package implementation .This may be attributed to the socioeconomic status, which has effects on women's knowledge as the income is considered one of the greatest factors that influenced the women's ability to receive complete nutritional information. These findings were supported by Ehab et al., (2020) who conducted study on maternal total energy, macronutrient and vitamin intakes during pregnancy associated with the offspring's birth size in the Japan environment and children's study and fund that was positively statistically significant about micronutrient elements. However, this finding of the present study agree with Aya et al.,(2019) who conducted study macronutrient and micronutrient intake during pregnancy: an overview of recent evidence and found that pregnant woman had good knowledge about micronutrient intake during 
pregnancy . On the other hand, this result is contradicted with Taddese \& Sibhatu.,(2018) who conducted study pregnant mothers have limited knowledge and poor dietary diversity practices, but favorable attitude towards nutritional recommendations in rural Ethiopia: evidence from communitybased study and found that Otherwise, no statistically significant difference was observed in all other food sources mentioned as sources of either vitamin A or iron .

Regarding attitude related to healthy nutrition during pregnancy among studied pregnant women, the finding of the present study there was a highly statistically significant difference regarding attitude related to healthy nutrition during pregnancy among studied pregnant women at pre and post phases of instructional package implementation $(\mathrm{P} \leq \mathrm{o}, \mathrm{oo} 1)$. This result may be due to the positive effect of the instructional package and the learning sessions.These findings were supported by Komeela et al., (2016) who found that a significant difference was observed in the pretest and post-test nutrition attitudes scores (mean change $=+0.2, \mathrm{p}<0.001)$. These findings were supported by Ooreoluwa et al.,(2018) who reported that knowledge, attitude and practice of good nutrition among women of childbearing age in Somolu Local government, Lagos State and found that there was statistically significant association between the knowledge of the respondents and their attitude towards good nutrition. This is in keeping with a previous study done in Manzini, Swaziland in which nutritional knowledge and attitude were significantly associated. Also, this finding of the present study agree with Sezer et al., (2017) who studies knowledge, attitudes and behaviors of pregnant women about food safety: a cross sectional survey and found that attitudes about food safety are generally positive. On the other hand, this result is contradicted with Dana ,(2018) who found that there was no significant association between maternal education and the attitude score. This shows that other predicting factors must be studied to have a better understanding of the factors that can influence women's attitude. Attitude may be related to women's intention irrespective of age, education and attendance of ANC. On the other hand, this result is contradicted with Taddese \& Sibhatu.,(2018) who found that ,attitude towards dietary diversity and better and adequate nutrition during pregnancy didn't showed statistically significant difference $(\mathrm{P}>0.05)$.

Regarding the correlation between total knowledge and total attitude among studied pregnant women ,the findings of the present study illustrated that there was statistical significant difference correlation between total knowledge and total attitude among studied pregnant women at pre phases of instructional package implementation( $\mathrm{P}$ $<0.05)$.While there was a highly statistically significant difference correlation between total knowledge and total attitude among studied pregnant women at post phases of instructional package implementation ( $\mathrm{P}$ $\leq$ o,oo1 ). This result may be due to good level of knowledge has positive effect on the level of attitude.These findings were supported by Hanan,(2019) who conducted study effect of nutrition education package on pregnant women knowledge and healthy dietary practice and found that there was appositive statistically correlation between total knowledge and total attitude scores before, immediately after, and at follow up phases of instructional package implementation( $\mathrm{p} \leq$ 0.0001). These findings are supported by Noha \& Asmaa .,(2019) who found that there is a statistically significant positive correlation between subject's level of knowledge about nutrition during pregnancy and energy, protein, calcium and copper dietary adequacy $(0.034,0.052,0.026$, and 0.037 , respectively.)On the other hand, this result is contradicted with Ehwarieme etal.,(2019)who conducted study on knowledge and practice of healthy nutrition among pregnant women attending antenatal clinic at selected private hospitals in Benin City and found that there is no significant difference in the knowledge of healthy nutrition and attitude of healthy nutrition 
among the respondents in the selected hospitals in Benin City. On the other hand, this finding of the present study disagree with Engy, (2020) who found that there were no significant differences regarding the knowledge and attitude about nutrition .

\section{Conclusion:}

The total knowledge and attitude score regarding healthy nutrition were greatly improved after instructional package implementation than before implementation among studied pregnant women . Also, there was a highly statistically significant difference regarding knowledge and attitude related to healthy nutrition during pregnancy among studied pregnant women at pre and post instructional package implementation ( $\mathrm{P}$ $\leq$ o,oo1 ).Moreover, there was statistical significant correlation between total knowledge and total attitude among studied pregnant women pre instructional package implementation $(\mathrm{P}<0.05)$. While there was a highly statistically significant correlation at post instructional package implementation ( $\mathrm{P}$ $\leq \mathrm{o}, \mathrm{oo} 1)$. Therefore, the study hypothesis was supported.

\section{Recommendations}

- Continuous health education programs to improve pregnant women's knowledge toward healthy nutrition during pregnancy.

-Applying Health belief model as a fram work for designing and performing education interventions to improve women's health attitude and beliefs regarding healthy nutrition.

-Posters and educational materials about healthy nutrition during pregnancy should be located in well-visible areas in outpatients' and private clinics.

- From time to time, the antenatal instructional package should be restructured and reviewed to meet up with the health needs of the pregnant women.

\section{Recommendations for Further researches:}

- Replication of the study on large representative probability sample is highly recommended in different maternity hospitals to achieve more generalization of the results.
-Activate the instructional package program for nurses to upgrade thier knowledge and attitude about importance of healthy nutrition for pregnancy.

\section{References}

Ade F. Adeniyi, Omoyemi O. Ogwumike, and Chidinma I. Osinike.,(2015). Physical activity and energy expenditure: findings from the Ibadan pregnant women's survey African journal of reproductive Health June 2015; 18(2): 117

Aya M, Amreen N\& Siew L. (2019). Macronutrient and Micronutrient Intake during Pregnancy: An Overview of Recent Evidence

Benjamin A, Kwabena $\mathbf{N}$, and Peter B,(2016). Socio-demographic and obstetric characteristics of anaemic pregnant women attending antenatal Clinic in Bolgatanga Regional Hospital Journal List scientific a (Cairo)v.2016; 4687342.

Berhe, B., Mardu, F.\& Legese, H. et al.,(2019). Prevalence of anemia and associated factors among pregnant women in Adigrat General Hospital, Tigrai, northern Ethiopia, 2018. BMC Res Notes12,310 (2019). https://doi.org/10.1186/s13104-0194347-4

Bookari K, Yeatman H, Williamson M (2016). Exploring australian women's level of nutrition knowledge during pregnancy: a cross-sectional study(2016) Published 16 August 2016 Volume 2016:8 Pages 405419 https://doi.org/10.2147/IJWH.S110072

Daba G, Beyene F, Fekadu H, Garoma W., (2015). Assessment of knowledge of pregnant mothers on maternal nutrition and associated factors in Guto Gida Woreda, East Wollega Zone, Ethiopia. J Nutr Food Sci 3: 235.

Dana H, Mohamad A H, \& Elie Y, .,(2018). Knowledge, attitude and practices toward nutrition and diet during pregnancy among recently delivered women of Syrian Refugees@ ULJRGH 2018 Vol 1, (2) . https://ir.library.louisville.edu/rgh.

Demilew, Y.M., Alene, G.D. \& Belachew, T. ,(2020). Dietary practices and associated factors among pregnant women in West 
Gojjam Zone, Northwest Ethiopia. BMC Pregnancy Childbirth 20, 18 (2020). https://doi.org/10.1186/s12884-019-2702-Z

Desta M., Akibu M., Tadese M., and Tesfaye M.,(2019). Dietary Diversity and Associated Factors among Pregnant Women Attending Antenatal Clinic in Shashemane, Oromia, Central Ethiopia: A Cross-Sectional Study, Journal of Nutrition and Metabolism,Vol.2019,page 1-7

Ehwarieme A. Timothy1 Amiegheme E. Felicia11 and Enosekhafoh B.,(2019): Knowledge and practice of healthy nutrition among pregnant women attending antenatal clinic at selected private hospitals in Benin City Vol. 11(7), pp. 75-86, July-September 2019 http://www.academicjournals.org/IJN ISSN: 2141-2456

Ekbal A E R E, Amany H A E R، Naglaa M A G\& Hanan E H., (2019):"American research journal of nursing. 2019; 5(1): 115. ISSN: 2379-2922 Volume 5, Issue 1, 15 Pages

Engy A A.,(2020): Effect of nutrition on pregnant women weight in Assiut Health Units Assiut Scientific Nursing Journal, Vol , (8) No, (20), March, 2020, pp (181-190) http://asnj.journals.ekb.eg http://www.arabimpactfactor.com

Ehab S. Eshak, C O, Sachiko B ,Takashi $K$ ،Satoyo Ik and Takuyo $S$,Kokoro $S$ and Hi B.,(2020) : Maternal total energy, macronutrient and vitamin intakes during pregnancy associated with the offspring's birth size in the Japan Environment and Children's Study Journal of Nutrition, page 1 of 9 u.ac.j(http://creativecommons.org/licenses/b $\mathrm{y} / 4.0 /)$

Estela G, Mayra C C, , Ricardo F, Rosa $M$ Ms, Cristina Rz, and Maricruz T.(2020). Factors associated with insufficient weight gain among Mexican pregnant women with HIV infection receiving antiretroviral therapy PLoS One. 2020; 15(5): e0233487. Published online 2020 May 22. /journal.pone.0233487

Fallah F, Pourabbas A, Delpisheh A, Veisani Y, Shadnoush M.,(2016). Effects of nutrition education on levels of nutritional awareness of pregnant women in Western Iran. International journal Endocrinology Metabolism . 2014; 11(3):175-178. /ijem.9122

Hanan A-E (2019). Effect of nutrition education package on pregnant women knowledge and healthy dietary practice IOSR Journal of nursing and health Science (IOSR-JNHS)e-ISSN: 2320-1959.pISSN: 2320-1940 Volume 8, Issue 1 Ver. I. (Jan. - Feb .2019), PP 38-44 www.iosrjournals.org www.iosrjournals.org 38 | Page

Heba Al-F I.,(2017). Diet Behavior Modification of Pregnant Woman with Iron Deficiency Anemia Using Construct of the Trans-Theoretical Model: A Theory-Based Study,www.iosrjournals.org 80 | Page IOSR Journal of Nursing and Health Science (IOSR-JNHS) e-ISSN: 2320-1959.p- ISSN: 2320-1940 Volume 6, Issue 3 Ver. VI (May - June 2017), PP 72-85

Herring CM, Bazer FW\& Johnson GA (2018). Impacts of maternal dietary protein intake on fetal survival, growth, and development. Exp Biol Med. 2018;243(6):525-33

https://doi.org/10.1111/mcn.12916

Jessica A, Reginald A Herman L, Anthony E, and Loh Su Peng., (2020).Prevalence of anaemia and low intake of dietary nutrients in pregnant women living in rural and urban areas in the Ashanti region of Ghana PLoS One. 2020; 15(1): e0226026. Published online 2020 Jan 24./journal.pone.0226026

Kara M.W, SaraW, Jihong LScD , StevenN.B\&,‘RussellR.P.,(2016).African

American and white women's perceptions of weight gain, physical activity, and nutrition during pregnancy midwifery 34(2016)211220

Karaponi O, Carol C, Shireen C, Marcus $H$ and Lesley M.,(2016). Knowledge and beliefs about nutrition and physical activity during pregnancy in women from South Auckland region, New Zealand Australian and New Zealand Journal of Obstetrics and Gynaecology 2016; 56: 471-483 
Koletzko B.,. Godfrey K., Poston L., Szajewska H., Goudoever J., Waard M., Brands R., Grivell R.,. Deussen A., Dodd J., Patro-Golab B., and Zalewski B.,(2019). Nutrition during pregnancy, lactation and early childhood and its implications for maternal and long-term child Health: The Early Nutrition Project Recommendations, Nutrition and Metabolism ,Vol.74,Page. 93-106.

Komeela C, Dhandevi P, Suress B, Rajesh J $\mathbf{N}$,(2016). Is a Nutrition Education Intervention Associated with a Higher Intake of Fruit and Vegetables and Improved Nutritional Knowledge among Housewives in Mauritius? Dec; 8(12): 723. Published online 2016 Nov 29. /nu8120723

Nahrisah P, Nahrisah H , Ratana Somrongthong,

Viriyautsahakul Napaphan Viwattanakulvanid , Samlee Plianbangchang et al.,(2020). Effect of integrated pictorial handbook education and counseling on improving anemia status, knowledge, food intake, and iron tablet compliance among anemic pregnant women in Indonesia: A Quasi-Experimental Study Journal of Multidisciplinary Healthcare 2020:13 43-52 available at https://www.dovepress.com/terms.

(http://creativecommons.org/licenses/by$\mathrm{nc} / 3.0 /)$.

Nana, A.\& Zema, T.,(2018). Dietary practices and associated factors during pregnancy in northwestern Ethiopia. BMC Pregnancy Childbirth 18, 183 (2018). https://doi.org/10.1186/s12884-018-1822-1

Ooreoluwa F, Olayinka A, and Foluke A. Fasola .,(2018). Knowledge, attitude and practice of good nutrition among women of childbearing age in Somolu Local Government, Lagos State J Public Health Afr. 2018 May 21; 9(1): 793. Published online $2018 \quad$ May 21.doi:10.4081/jphia.2018.793 Journal ListJ Public Health Afrv.9(1); 2018 May 21.

Oumer A.,(2019). Knowledge, attitude and practice of pregnant mothers towards preventions of Iron deficiency anemia in Ethiopia: Institutional based cross sectional study. health care current reviews 7: 238.4273.19.07.238.

Noha M M\& Asmaa S G.,(2019). Dietary Knowledge, Practices and Adequacy among Bedouin Pregnant Women International Journal of Nursing December 2019, Vol. 6, No. 2, pp. 68-83 ISSN 2373-7662 (Print) 2373-7670 ijn.v6n2a7 URL: https://doi.org/: 10.15640/ijn.v6n2a7

Paknahad Z., Fallah A., and Moravejolahkami A.,(2019). Maternal dietary patterns and their association with pregnancy outcomes, Clin Nutr Res. ,Vol. 8,No. 1,Page 64-73.

Rupali Datta., (2020). Busting diet myths about what to eat or avoid during pregnancy Updated: March 09, 2020 11:22 IST https://food.ndtv.com/fooddrinks/international-womens-day-2020busting-diet-myths-about-what-to-eat-oravoid-during-pregnancy-2191516

Sarah L Killen, Shauna L. C, Chandni M J, Mark A. H\& Fionnuala M. McA, (2020). "It only takes two minutes to ask"-a qualitative study with women on using the FIGO Nutrition Checklist in pregnancy, International Journal of Gynecology \& Obstetrics,10.1002/ijgo.13322, 151, S1, (4550), (2020).

Sezer Er Guneri, Selma Sen, Duygu Gulec Satir, Rusen Ozturk, Nuray Egelioglu Cetisl.\& Ahsen Sirin (2017). Knowledge, attitudes and behaviors of pregnant women about food safety: a cross sectional survey International Journal of caring Sciences May- August 2017 Volume 10 | Issue 2| Page

704 www.internationaljournalofcaringsciences.o rg

Sharma, S., Kaur, S.P. \& Lata, G.,(2020). Anemia in pregnancy is still a public health problem: a single center study with Review of Literature. Indian $\mathbf{J}$ Hematol Blood Transfus 36, 129-134 (2020). https://doi.org/10.1007/s12288-019-01187-6 Sunuwar D., Sangroula R., Shakya N., Renu Yadav R., Chaudhary N., and PradhanI P.,(2019). Effect of nutrition education on hemoglobin level in pregnant 
women: A quasi experimental study, PLoS ONE ,Vol.14(3),Page 1-12

Taddese Alemu Zerfu, Sibhatu Biadgilign.,(2018). Pregnant mothers have limited knowledge and poor dietary diversity practices, but favorable attitude towards nutritional recommendations in rural Ethiopia: evidence from communitybased studyBMC Nutr. 2018; 4: 43. Published online 2018 Dec 20. Journal List BMC Nutrv.4; 2018PMC705094

T. Morris, S. Strömmer, C. Vogel, N. C. Harvey, C. Cooper, H. Inskip, K. WoodsTownsend, J. Baird, M. Barker, and W. Lawrence.,(2020): Improving pregnant women's diet and physical activity behaviours: the emergent role of health identity BMC Pregnancy Childbirth. 2020; 20: 244. Published online 2020 Apr 25.

Tahir M., Haapala J., Foster L., Duncan K., Teague A., Kharbanda E., McGovern P., Whitaker K., Kathleen M. Rasmussen K., Fields D., Jacobs D.,. Harnack L., and Demerath E.,(2019). Higher maternal diet quality during pregnancy and lactation is associated with lower Infant weight-forlength, body fat percent, and fat mass in early postnatal Life,Nutrients, Vol.11,No.632,Page 2-14.

Temesgen $G \&$ Ayenew $N$ (2020). Predictors of malnutrition among Pregnant Women in Ethiopia: Systematic Review and Meta-Analysis https://doi.org/10.21203/rs.3.rs-34039/v1 https://orcid.org/0000-0002-5645-0006

Tsegaye D, Tamiru D, Belachew T(2020). Factors associated with dietary practice and nutritional status of pregnant women in rural communities of Illu Aba Bor Zone, Southwest Ethiopia Published 23 July 2020 Volume 2020:12 Pages 103-112 https://doi.org/10.2147/NDS.S257610 Ülger T. G. Akçalı Ç. \& Yardımcı H.,(2018). Evaluation of nutrition education during pregnancy and nutritional knowledge of pregnant women.

Wemakor A., (2019). Prevalence and determinants of anaemia in pregnant women receiving antenatal care at a tertiary referral hospital in Northern Ghana. BMC Pregnancy Childbirth19, 495 (2019). https://doi.org/10.1186/s12884-019-2644-5 Yan, H., Dang, S.\& Zhang, Y. et al. (2020). Dietary patterns of Chinese women of childbearing age during pregnancy and their relationship to the neonatal birth weight. Nutr J 19, 89 (2020). https://doi.org/10.1186/s12937-020-00607-y Yu Qi Lee, Jason L, Rebekah Su E.A,\& Mary F.F C., (2020). Tracking of maternal diet from pregnancy to post pregnancy: a systematic review of observational studies, current developments in

Nutrition, 10.1093/cdn/nzaa118, 4, 8, (2020)

Zelalem A, Endeshaw M, Ayenew M, Shiferaw S\& Yirgu R., (2017). Effect of nutrition education on pregnancy specific nutrition knowledge and healthy dietary practice among pregnant women in Addis Ababa. Volume 14 • Issue 3 • 1000265 Clinics Mother Child Health 14: 265. 


\section{تأثير الحزمة الإرشادية على معرفة واتجاه السيدات الحوامل فيما يتعلق بالتغذية الصحية} عزة عبد الحميد عبد القتاح أحمد - .عحم عبد السلام عحم ـ سعاد عبد السلام رمضان ـ أميرة محمد سلامة

تساعد التغذية الصحية أثناء الحمل على الحفاظ على النمو الطبيعي للجنين وتطوره ، وتحسين نتائج الولادة و الوقاية من أمر اض الطفولة في وقت لاحق من الحياة. لذلك هدفت هذه الدر اسة الى تقييم تأثير الحزمة التعليمية على معرفة المرأة الحامل وموقفها فيما يتعلق بالتغذية الصحية. وقد اجريت هذه الدراسة في عيادة التوليد و أمر اض النساء الخارجية في مستشفى جامعة بنها على ، . 1 امر أة حامل حيث كثفت النتائج عن تحسن كبير بعد تنفيذ الحزمة التعليمية أكثر من قبل التنفيذ بين النساء الحوامل الخاضعات للار اسةو ايضا تحسن اتجاتهم فيما يتعلق بالتغذية الصحية بشكل كبير بعد تنفيذ الحزمة التعليمية أكثر من قبل التنفيذ بين النساء الحوامل.كما اوصت الدر اسه بوضع الملصقات والمو اد التعليمية حول التغذية الصحية أثناء الحمل في مناطق مرئية جيدًا في العيادات الخار جية و العيادات الخاصة. 